\title{
A water quality index for use with diatoms in the assessment of rivers
}

\author{
Guy Bate*, Pat Smailes and Janine Adams \\ Department of Botany, University of Port Elizabeth, PO Box 1600, Port Elizabeth 6000, South Africa
}

\begin{abstract}
Water quality is commonly reported with respect to the minerals that comprise the total dissolved solids, often together with COD, BOD, $\mathrm{pH}$ and other components. For ease of use by consumers, the quality parameters are mostly related to usage, i.e. water quality for domestic use, livestock or irrigation, etc. When diatom populations are used as water quality indicators a different system is necessary because diatoms are mostly good indicators of the total dissolved solids. A system to report water quality as an index or class is proposed using data collected from the Swartkops River system, which has pristine headwaters but which becomes progressively polluted downstream. The data included in the index encompass water quality values that cover more than $90 \%$ of the 212 river sites sampled from all the phytogeographical areas of South Africa.
\end{abstract}

Keywords: epipelic diatoms; river water quality; water quality index

\section{Introduction}

There is a great need for good quality water throughout the world and this is no different in South Africa. Consumption is beginning to exceed supply in many areas as the population grows, with industrial and agricultural requirements increasing in proportion. Most rivers in South Africa have been modified, primarily by weirs and dams, to increase their year-round ability to supply water for agriculture, industry, municipal and human purposes. Many of these modifications have resulted in a reduction of water quality within the rivers because return flow from irrigated agricultural lands and sewage purification works has increased the total dissolved solids in many rivers. Due to agricultural activities, erosion has become a problem and this has increased the already naturally high turbidity of many rivers.

The Department of Water Affairs and Forestry (DWAF) at Resource Quality Services monitors the water chemistry of many rivers in South Africa. However, the chemistry at any given time is a snapshot of the water quality at the time of sampling. The temporal variation of most water quality variables is usually high in lotic environments (France and Peters, 1992; Chambers et al., 1992; Cattaneo and Prairie, 1995) and biological monitors can be beneficial if they can accurately assess the water quality with a lower degree of variability than can the snap-shot samples at different sites and of specific water quality variables (Stevenson and Pan, 1999).

In 1996 DWAF, the Water Research Commission (WRC) and the Department of Tourism, Environmental and Economic Affairs (DTEEA) initiated the National Biomonitoring Programme for Aquatic Ecosystems (NBPAE). The objective was to design a programme to monitor the health of aquatic ecosystems throughout the country and to provide information that might be used to manage water systems (Hohls, 1996). Arrays of biological indices have, and are, being tested for practical use and interpretation. These indices

* To whom all correspondence should be addressed.

푱+2733 330 5252; e-mail: bate@telkomsa.net

Received 10 March 2004; accepted in revised form 27 July 2004. include the South African Scoring System Version 5(SASS5, based on macroinvertebrates), the Index of Biotic Integrity (IBI based on fish) and the Riparian Vegetation Index (RVI). A suite of secondary indices is also used to interpret the biological indices. These include habitat assessment indices, the Hydrological Index, the Water Quality Index (WQI) and geomorphological indices.

The use of benthic diatoms in South Africa for water quality assessment has been briefly considered, but until recently the shortage of expertise in identification made a diatom index unsuitable for use (Uys et al., 1996). Despite this, in South African river systems, diatoms have been studied extensively since the early 1950s (e.g. Cholnoky, 1953; Cholnoky, 1960; Cholnoky, 1968; Archibald, 1983) and efforts have been made to relate diatom associations to water quality (e.g. Archibald, 1983; Schoeman, 1979; Schoeman and Archibald, 1986). However, none of these has included the complete suite of parameters routinely measured by Resource Quality Services. Hence, these earlier observations are incomplete by present-day standards.

The distribution of benthic algae in a river is the result of a complex series of interactions between hydrological, water quality and biotic factors. Short-term differences in community composition are driven by immigration of cells, differences in growth rate between populations and loss processes such as death, emigration, sloughing and grazing. Poulin and Williams (1998) estimated that there are 10 million diatom species world-wide of which only about 11000 have been identified to date. However, Bate et al. (2004) have shown during an extensive survey of South African rivers that the number of dominant benthic diatom species is remarkably low. Lange-Bertalot (2000) suggested that part of the international species pool is cosmopolitan and Bate et al. (2004) have confirmed this because most of the dominant species found in the South African rivers were already recorded in the international literature.

Benthic microalgae become abundant where water systems are impacted by anthropogenic influences. Diatom autecology has been studied in various parts of the world and diatom indices for the assessment of water quality have been developed (e.g. Prygiel and Coste, 1993; Kelly and Whitton, 1995). Various researchers have been able to infer successfully the trophic conditions at a sampling 


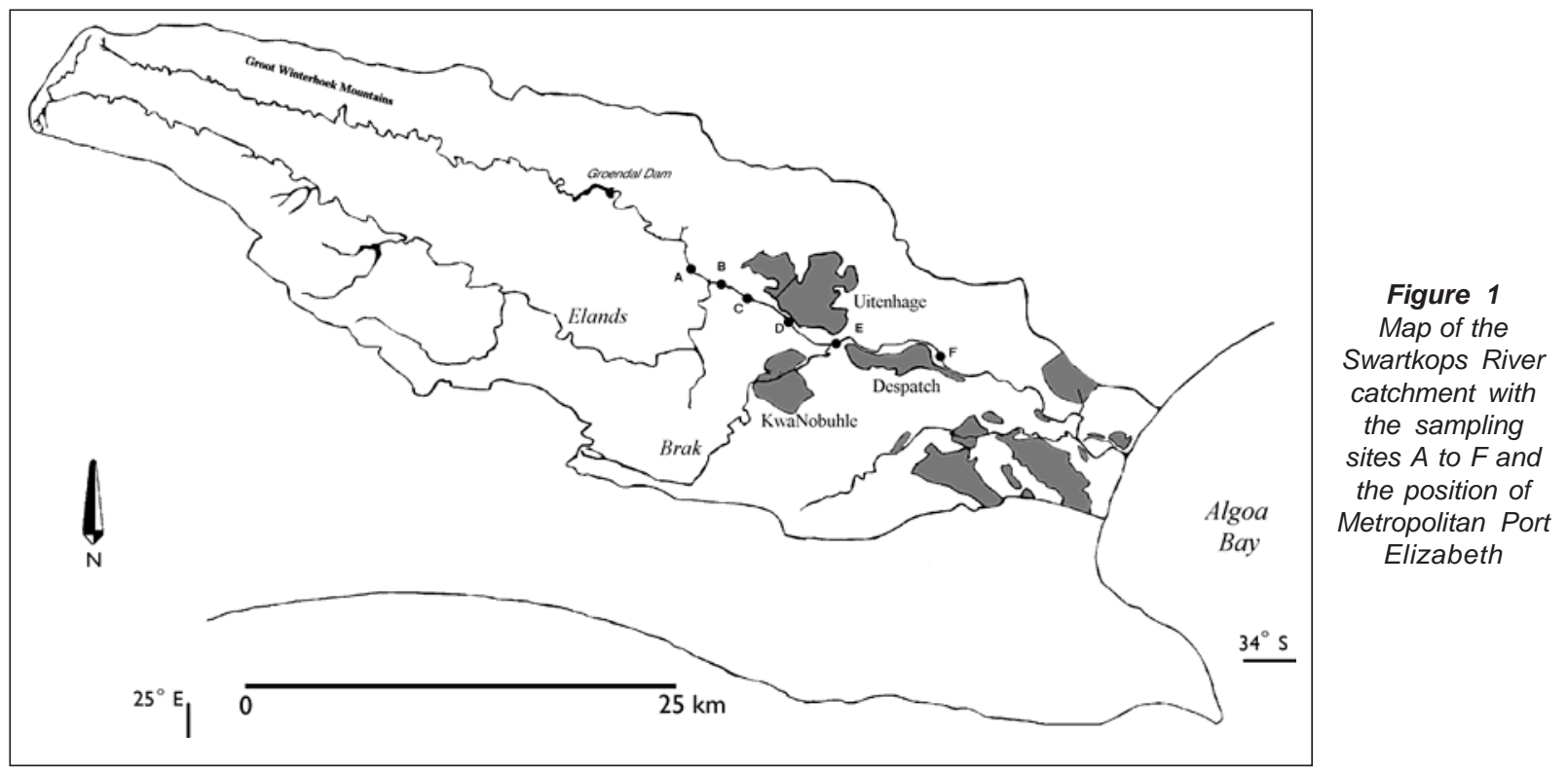

site from the composition of benthic diatom assemblages at that site (e.g. Van Dam et al., 1994; Kelly and Whitton, 1995). This indicates that trophic conditions do have an influence on species composition, but that it is hard to distinguish specific nutrients causing the effect. Nutrient kinetic studies and multivariate statistics are promising approaches to study the effect of nutrients on benthic algal species composition (Borchardt, 1996).

The assessment of water quality conditions in freshwater habitats with benthic diatoms has a long history. Diatoms are used as bioindicators in Europe (Kelly et al., 1998; Prygiel et al., 1999), North America (Stevenson and Pan, 1999; Lowe and Pan, 1996), South America (Lobo et al., 1998; Loez and Topalian, 1999), Australia (John, 1998; Chessman et al., 1999) Asia (Lobo et al., 1995; Rothfritz et al., 1997) and Africa (e.g. Schoeman, 1979; Pieterse and Van Zyl, 1988; Gasse et al., 1995). Some of these approaches are focused on inferring past hydrochemical characteristics in lakes (e.g. Fritz et al., 1991; Gasse et al., 1995), while others are designed to monitor present-day conditions in rivers and streams (e.g. Prygiel and Coste, 1999).

Currently in South Africa an array of biological indices is being tested for practical use in the interpretation of water quality. These indices are not used uniformly throughout South Africa because the different assessments are fragmented into usage characteristics. For example "hard water" is water with certain characteristics; water suitable for the different kinds of livestock in the country has certain characteristics while water quality suitable for a sustainable ecosystem must have a quality variance that should not exceed a percentage of the natural values. Clearly these latter indices are unsuitable for use where diatoms are used to express the quality of natural river water.

A water quality index, in the context of this report, is a set of numerical values to indicate the concentration of chemical constituents present in river water. A water quality class is a numerical value that can be used with diatoms to indicate the average of all the chemical constituents present in river water at the site where a species was found. The components of the final index provide a rapid assessment of how the final class is calculated. The WQI is "arbitrary" in the sense that the values have no biological or chemical reason for being used, but simply reflect a case for comparison. Bate et al. (2004) have reported on the relationships between water quality and the dominant benthic diatom flora in a great many of
South Africa's rivers. The water quality values used by these authors included the normal suite assessed by Resource Quality Services. This present paper describes a numerical index system that indicates how the dominant diatom species found at a site indicates the water quality.

\section{Materials and methods}

\section{Water quality: Swartkops River}

The data from which the water quality index is derived were taken from the Swartkops River in the Eastern Cape South Africa. The main part of the catchment of the Swartkops River lies in the "Groot Winterhoek Mountains" (Fig. 1). The total catchment area is ca. $1354 \mathrm{~km}^{2}$ with a mean annual runoff of $84.2 \times 10^{6} \mathrm{~m}^{3}$. The largest obstruction to river flow in the catchment is the Groendal Dam. This reservoir has a storage capacity of ca. $12 \times 10^{6} \mathrm{~m}^{3}$, which is $45 \%$ of the mean annual runoff from that part of the catchment. The Elands River is the largest tributary to the Swartkops and has two small dams in its catchment. These dams tend to have little effect on the river flow (Baird et al., 1986). The part of the Swartkops River that was studied is a $2^{\text {nd }}$ to $3^{\text {rd }}$ order stream (Strahler method in Gordon et al., 1992) based on a 1:250 000 scale map. The climate in the catchment is largely warm temperate with all months between 10 to $22^{\circ} \mathrm{C}$ and with at least $60 \mathrm{~mm}$ of rain monthly (Köpke, 1988). Six sites (A to F) were selected along the river that was regularly sampled as part of a monitoring programme run by DWAF. The locations of the sites are given in Table 1 . Figure 1 illustrates the catchment area and sampling sites.

The water quality of the Swartkops River is severely impacted by several anthropogenic sources (Baird, 1986; Mackay, 1993; Binning, 1999). There is a persistent gradient of water quality, ranging from virtually pristine conditions just upstream from the town of Uitenhage(Sites A and B), to heavily degraded water quality at Sites $\mathrm{C}$ to F. The sources of impact include: agriculture, a woolprocessing factory, three sewerage treatment works, runoff from informal settlements and discharges from light industries (e.g. leather tanning).

The sampling sites were visited monthly between May 1997 and April 1999 and the full suite of major inorganic water quality variables was analysed by the RQS of DWAF. The details of these sites are shown in Table 1. 
River samples for water quality and dominant epipelic diatoms were collected in the Western Cape, Free State, Northern Cape, KwaZulu-Natal, Northern Province, Eastern Cape, Kruger National Park, Durban Metro area and DWAF Rand Water area. Full details of the 212 sampling sites, GPS co-ordinates and date of sampling are given in Bate et al., 2004.

\section{Water quality analyses}

The water samples ( $250 \mathrm{~m} \ell$ ) were taken by the DWAF representative present during the collection, preserved with $\mathrm{HgCl}_{2}\left(8 \mathrm{mg} \cdot \ell^{-1}\right)$ and analysed at the laboratories of the Resource Quality Services, Department of Water Affairs and Forestry, Pretoria, South Africa (National Laboratory Accreditation Service, Accredited Laboratory No. T0073). The samples were analysed for $\mathrm{NH}_{4}, \mathrm{NO}_{2}+\mathrm{NO}_{3}, \mathrm{~F}$, alkalinity as $\mathrm{CaCO}_{3}$, $\mathrm{Na}, \mathrm{Mg}, \mathrm{Si}, \mathrm{PO}_{4}, \mathrm{SO}_{4}, \mathrm{Cl}, \mathrm{K}, \mathrm{Ca}$ and total dissolved solids (TDS). In situ dissolved oxygen (WTW, Oxi 330), electrical conductivity (YSI model 30 conductivity meter), $\mathrm{pH}$ (UniFet $100 \mathrm{pH}$ meter) and temperature (read from the conductivity meter) were measured. In those cases where the samples were taken by Rand Water, Durban Metro and Umgeni Water, the water samples were handled and treated in their own prescribed manner.

\section{Calculation of the Swartkops River water quality classes and water quality index for diatoms}

The presentation of diatom data as an indication of water quality can be by simply showing the actual water quality values of the sites in which the diatom species were found. The problem with that approach is that the reader is left without any perspective of where the species lies in the context of all South African water quality values. If an index of water quality were to have been constructed from all the water quality data collected in this project, the spread would be great and therefore not very useful. For this reason the choice was made to construct an arbitrary index but one using real data from the Swartkops River. The Swartkops River data are useful because they represent a consecutive 13-month collection of water samples from sites with consistently different water quality. Sediment samples were collected at the same time that the water samples were collected and the dominant diatoms from each site were related to the water quality in the river (Bate et al., 2004).

The minimum and maximum values for each water quality parameter was calculated for the Swartkops River and compared with all the South African river sites. Five water quality classes were compiled using the Swartkops water quality data. To determine the water quality index for a diatom species the average water quality value is calculated and a water quality class (i.e. 1 to 5) assigned. There are too few replicated diatom data at present to use this water quality index system as more than a guide.

\section{Results}

The water quality data taken from the Swartkops River are shown in Table 2 and illustrate that the ranges between minimum and maximum values for these data are narrower than for the "all South Africa” (RSA) data. To construct an index from the wide-ranging data set from all the RSA data results in lower sensitivity.

Of importance is the fact that the data in Table 2 show that the maximum values of the Swartkops River data cover 90 to $100 \%$ of
TABLE1

Sampling sites on the Swartkops River indicating the site designation, its name and the location co-ordinates

\begin{tabular}{|l|l|l|}
\multirow{2}{*}{ Name } & \multicolumn{2}{|c|}{ Location } \\
\cline { 3 - 4 } & South & East \\
\hline Springfontein & $33^{\circ} 44^{\prime} 10.5^{\prime \prime}$ & $25^{\circ} 19^{\prime} 11.3^{\prime \prime}$ \\
Bulmer Drift & $33^{\circ} 45^{\prime} 07.6^{\prime \prime}$ & $25^{\circ} 20^{\prime} 33.4^{\prime \prime}$ \\
Gubb \& Ingg's & $33^{\circ} 45^{\prime} 51.2^{\prime \prime}$ & $25^{\circ} 22^{\prime} 32.9^{\prime \prime}$ \\
& $33^{\circ} 46^{\prime} 19.5^{\prime \prime}$ & $25^{\circ} 23^{\prime} 16.5^{\prime \prime}$ \\
Niven Bridge & $33^{\circ} 47^{\prime} 33.1^{\prime \prime}$ & $25^{\circ} 24^{\prime} 48.4^{\prime \prime}$ \\
Nic Claasen Bridge/Brak River & $33^{\circ} 47^{\prime} 25.2^{\prime \prime}$ & $25^{\circ} 29^{\prime} 18.6^{\prime \prime}$ \\
Despatch Bridge & \multicolumn{2}{|}{}
\end{tabular}

\begin{tabular}{|c|c|c|c|c|c|}
\hline \multicolumn{6}{|c|}{$\begin{array}{l}\text { TABLE2 } \\
\text { Minimum and maximum values for each of the } \\
\text { parameters measured at the Swartkops River } \\
\text { sites together with the minimum and maximum } \\
\text { values measured at all the sites sampled in South } \\
\text { Africa during the study. The data show the maxi- } \\
\text { mum value from the Swartkops River sites as a } \\
\text { percentile of the "all South Africa" maximum value } \\
\text { measured. The values given are those provided by } \\
\text { WQS. }\end{array}$} \\
\hline Component & $\begin{array}{c}\text { SR WQ } \\
\text { Min } \\
\text { Value }\end{array}$ & $\begin{array}{c}\text { SR WQ } \\
\text { Max } \\
\text { Value }\end{array}$ & $\begin{array}{c}\text { All } \\
\text { RSA } \\
\text { WQ } \\
\text { Min } \\
\text { Value }\end{array}$ & $\begin{array}{c}\text { All } \\
\text { RSA } \\
\text { WQ } \\
\text { Max } \\
\text { Value }\end{array}$ & $\begin{array}{c}\text { SR WQ } \\
\text { max. } \\
\text { as a } \\
\% \text { ile }\end{array}$ \\
\hline $\mathrm{Ca}$ & 2 & 90 & 1 & 504 & 94.9 \\
\hline $\mathrm{Cl}$ & 40 & 1577 & $<10$ & 6844 & 99.3 \\
\hline F & 0 & 0.5 & $<10$ & 0.7 & 96.4 \\
\hline K & 0.6 & 34.2 & 0 & 242.6 & 94.3 \\
\hline Mg & 3 & 129 & 1 & 690 & 98.8 \\
\hline $\mathrm{Na}$ & 24 & 899 & $<0.02$ & 3645 & 99.4 \\
\hline $\mathrm{NH}_{4}$ & 0 & 3.8 & $<0.04$ & 295 & 99.4 \\
\hline $\mathrm{NO}_{3}^{4}+\mathrm{NO}_{2}$ & 0 & 6.2 & $<0.04$ & 340 & 96.8 \\
\hline $\mathrm{pH}^{3}$ & 6.81 & 8.8 & 4.2 & 9.6 & 97.9 \\
\hline $\mathrm{PO}_{4}$ & 0.01 & 7 & $<0.01$ & 336 & 93.1 \\
\hline $\mathrm{SiO}_{2}$ & 0 & 8.9 & 0.5 & 47 & 92.8 \\
\hline $\mathrm{SO}_{4}$ & 0 & 514 & 2.1 & 2114 & 98.1 \\
\hline Alkalinity & 7 & 851 & 6 & 851 & 100 \\
\hline TDS & 95 & 3380 & 26.1 & 14139 & 99 \\
\hline
\end{tabular}

all the values taken from 212 river sites in all the obvious phytogeographical regions of South Africa.

An analysis of the water quality values obtained for all the South African sites (Bate et al. 2004) showed that the data, with the exception of $\mathrm{pH}$, were not normally distributed. Rather they were made up of many low values with very few high values. The data for TDS are shown in Fig. 2.

In compiling water quality classes using the Swartkops River quality data, a decision was taken that 5 classes would be adequate. The determination of a class is that Class 1 begins at the lowest value of a water quality component found from the Swartkops River data shown in Table 3, while a Class 2 has the range (Class 2 minus Class 1)/2. The same principle applies to the other classes.

Anomalies occur where the water quality at a site is either below 


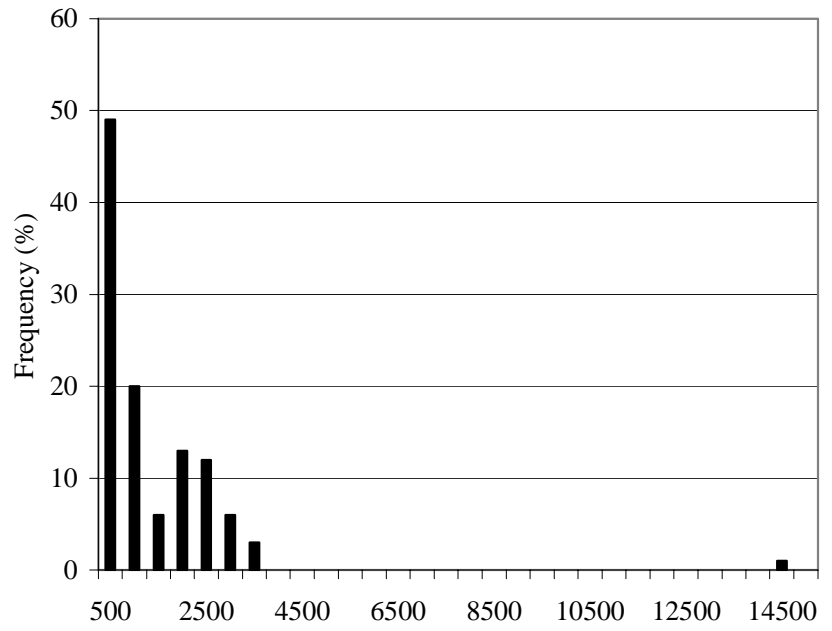

TDS (mg. ${ }^{-1}$ )

Figure 2

Frequency distribution of total dissolved solids from all the rivers sampled in South Africa

the minimum of the index range or above its maximum. This can be accommodated logically in cases where the number is higher than the maximum in the Swartkops classes, by applying a suffix to the class value, where relevant. Hence, it is possible to have a Class 1- or a Class $5+$. In the event that a site value exceeded the upper Class 5 value by an order of magnitude, a Class $5++$ would be indicated. Hence, in the case of TDS, values falling between 95.0 and 505.63 were allocated Class 1, whereas values $>505.63$ to 1326.88 were allocated Class 2 and so on. If a TDS value was found to be $>3380$ $\mathrm{mg} \cdot \ell^{-1}$ (Table 2 ) then it was classified as $5+$. The actual calculations were undertaken using MS Excel using nested conditional statements.
To determine the water quality index (WQI) for a diatom species, the average water quality values for the site where the species was found were calculated for each component as shown in Table 4. Hence the WQI for a diatom species would comprise the average value of the water quality components. An example is shown in Table 4 for the diatom with the code name AMPHPEDI (Amphora pediculus (Kutzing) Grunow). Code names were allocated according to the rules determined by Bate et al. (2004). An example of this calculation is provided with reference to Tables 3 and 4. In Table 4, AMPHEDI is shown to have been found at a site where the $\mathrm{Ca}^{++}$concentration was $69 \mathrm{mg} \cdot \ell^{-1}$. This value falls between 57 and 79 (Table 4) and thus a Class 4 is allocated for $\mathrm{Ca}^{++}$. Similarly, the $\mathrm{Cl}^{-}$concentration was $463 \mathrm{mg} \cdot \ell^{-1}$, which falls between 232 and 616, thus placing $\mathrm{Cl}^{-}$in Class 2.

The average value on the last line of Table 4 indicates that all values are included in the calculation except $\mathrm{pH}$. The reasons for excluding $\mathrm{pH}$ are that:

- The pH data were the only ones that were normally distributed

- A low or high pH value does not necessarily indicate good or poor water quality.

The calculation of the average class includes EC and TDS. It might be argued that EC should be excluded since it is a measure of TDS and thus TDS is included twice. The data for all the water quality data across South Africa (Bate et al., 2004) showed that the TDS could be calculated as EC x 6.49 with the range 3.74 to 9.27. The majority of the TDS/EC values were very close to 6.5. The reason for including EC into the diatom WQI is that Resource Quality Services normally include it in their reports and the class is the same as that for TDS.

Because the final WQI is the mean of the components, the influence of including EC is almost negligible. A number of examples were calculated (data not shown) before this procedure was followed.

TABLE3

Water quality class ranges for each water quality component. Data taken from the Swartkops River at 5 sites over a period of 13 months. In each class range, "Low" represents the lowest value measured while "High" represents the highest value measured ( $\mathrm{mg} \cdot \ell^{-1}$ for mineral elements; $\mathrm{mS} \cdot \mathrm{m}^{-1}$ for $\mathrm{EC}$; $\mathrm{pH}$ units).

\begin{tabular}{|l|c|c|c|c|c|c|c|c|c|c|}
\hline \multirow{2}{*}{$\begin{array}{l}\text { Compo- } \\
\text { nent }\end{array}$} & \multicolumn{2}{|c|}{ Class 1 Range } & \multicolumn{2}{c|}{ Class 2 Range } & \multicolumn{2}{c|}{ Class3 Range } & \multicolumn{2}{c|}{ Class 4 Range } & \multicolumn{2}{c|}{ Class 5 Range } \\
\cline { 2 - 11 } & Low & High & Low & High & Low & High & Low & High & Low & High \\
\hline $\mathrm{Ca}^{++}$ & 2.00 & 13.00 & $>13$ & 35.00 & $>35.00$ & 57.00 & $>57.00$ & 79.00 & $>79.00$ & 90.00 \\
$\mathrm{Cl}^{-}$ & 40.00 & 232.13 & $>232.13$ & 616.38 & $>616.38$ & 1000.63 & $>1000.63$ & 1384.88 & $>1384.88$ & 1577.00 \\
$\mathrm{EC}$ & 17.30 & 128.01 & $>128.01$ & 349.44 & $>349.44$ & 570.86 & $>570.86$ & 792.29 & $>792.29$ & 903.00 \\
$\mathrm{~F}^{-}$ & 0.00 & 0.05 & $>0.05$ & 0.15 & $>0.15$ & 0.25 & $>0.25$ & 0.35 & $>0.35$ & 0.40 \\
$\mathrm{~K}^{+}$ & 0.60 & 30.85 & $>30.85$ & 91.35 & $>91.35$ & 151.85 & $>151.85$ & 212.35 & $>212.35$ & 242.60 \\
$\mathrm{Mg}^{++}$ & 3.00 & 18.75 & $>18.75$ & 50.25 & $>50.25$ & 81.75 & $>81.75$ & 113.25 & $>113.25$ & 129.00 \\
$\mathrm{Na}^{+}$ & 24.00 & 133.38 & $>133.38$ & 352.13 & $>352.13$ & 570.88 & $>570.88$ & 789.63 & $>789.63$ & 899.00 \\
$\mathrm{NH}_{4}^{+}$ & 0.00 & 0.48 & $>0.48$ & 1.43 & $>1.43$ & 2.38 & $>2.38$ & 3.33 & $>3.33$ & 3.81 \\
$\mathrm{NO}_{2}^{-}+\mathrm{NO}_{3}^{-}$ & 0.00 & 0.78 & $>0.78$ & 2.33 & $>2.33$ & 3.89 & $>3.89$ & 5.44 & $>5.44$ & 6.22 \\
$\mathrm{pH}^{-}$ & 6.81 & 7.07 & $>7.07$ & 7.58 & $>7.58$ & 8.10 & $>8.10$ & 8.61 & $>8.61$ & 8.87 \\
$\mathrm{H}_{2} \mathrm{PO}_{4}^{-}$ & 0.01 & 0.88 & $>0.88$ & 2.62 & $>2.62$ & 4.36 & $>4.36$ & 6.10 & $>6.10$ & 6.97 \\
$\mathrm{SiO}_{2}$ & 0.00 & 1.11 & $>1.11$ & 3.34 & $>3.34$ & 5.56 & $>5.56$ & 7.79 & $>7.79$ & 8.90 \\
$\mathrm{SO}_{4}^{++}$ & 0.00 & 64.25 & $>64.25$ & 192.75 & $>192.75$ & 321.25 & $>321.25$ & 449.75 & $>449.75$ & 514.00 \\
$\mathrm{Alkalinity}^{+}$ & 7.00 & 112.50 & $>112.50$ & 323.50 & $>323.5$ & 534.50 & $>534.5$ & 745.50 & $>745.50$ & 851.00 \\
$\mathrm{TDS}^{-00}$ & 95.00 & 505.63 & $>505.63$ & 1326.88 & $>1326.88$ & 2148.13 & $>2148.13$ & 2969.38 & $>2969.38$ & 3380.00 \\
\hline
\end{tabular}




\begin{tabular}{|c|c|c|}
\hline \multicolumn{3}{|c|}{$\begin{array}{c}\text { TABLE4 } \\
\text { Calculation of the diatom WQI for the single } \\
\text { diatom species with the code name AMPHEDI } \\
\text { (Amphora pediculus (Kutzing) Grunow) }\end{array}$} \\
\hline $\begin{array}{l}\text { AMPHPEDI } \\
\text { Component }\end{array}$ & $\begin{array}{l}\text { Quantity } \\
\left(\mathrm{mg} \cdot \ell^{-1}\right)\end{array}$ & $\begin{array}{l}\text { DiatomwQ } \\
\text { Index }\end{array}$ \\
\hline $\mathrm{Ca}^{++}$ & 69 & 4 \\
\hline $\mathrm{Cl}^{-}$ & 463 & 2 \\
\hline $\mathrm{EC}\left(\mathrm{mS} \cdot \mathrm{m}^{-1}\right)$ & 238 & 2 \\
\hline $\mathrm{F}^{-}$ & 0.5 & 5 \\
\hline $\mathrm{K}^{+}$ & 8.9 & 1 \\
\hline $\mathrm{Mg}^{++}$ & 46 & 2 \\
\hline $\mathrm{Na}^{+}$ & 319 & 2 \\
\hline $\mathrm{NH}_{4}^{-}$ & 0.02 & 1 \\
\hline $\mathrm{NO}_{3}^{-}$ & 0.02 & 1 \\
\hline $\mathrm{pH}^{3}$ & 8.35 & 4 \\
\hline $\mathrm{H}_{2} \mathrm{PO}_{4}^{-}$ & 0.043 & 1 \\
\hline $\mathrm{SiO}_{2}$ & 2.4 & 2 \\
\hline $\mathrm{SO}_{4}^{-2}$ & 245 & 3 \\
\hline Alkalinity & 196 & 2 \\
\hline TDS & 1391 & 3 \\
\hline AVE CLASS WITHOUT $\mathrm{pH}$ & & 2.21 \\
\hline
\end{tabular}

To construct an index from the wide-ranging data set from all the RSA data results in lower sensitivity. On the other hand, some of the Swartkops maximum values are as high as or almost as high as the maximum values from all the RSA rivers sampled. It might therefore appear unnecessary to use the Swartkops River data. As mentioned, however, the component values from all RSA rivers had a few very high values. In the case of TDS the greatest TDS value from the Swartkops River was $3380 \mathrm{mg} \cdot \ell^{-1}$ whereas the highest value from all RSA sites was $14139 \mathrm{mg} \cdot \ell^{-1}$.

The use of a Water Quality Index allows one to assess rapidly the overall water quality of the site where the diatom species was found. At the same time, the quality of the water for each of the components can also be rapidly determined.

\section{Discussion}

A water quality index, in the context of this study, is a set of numerical values to indicate the concentration of chemical constituents present in river water. This water quality index is a numerical value that can be applied to diatoms indicating the average of all the chemical constituents present in river water at the site where the species was found. The WQI is "arbitrary" in the sense that the values have no biological or chemical reason for being used, but simply reflect a case for comparison. The water quality index values chosen in this study were taken from the Swartkops River in the Eastern Cape, South Africa, because those data were the most comprehensive available. More particularly, they represent water quality data from a system that has a wide variation in water quality from headwaters to the head of the estuary.

We believe that the water quality index reported here is a valuable addition to the description of river water quality as well as to the uses to which water can be put. For example, where domestic water is considered to have a target TDS of 0 to $450 \mathrm{mg} \cdot \ell^{-1}$, this implies that the target water quality index value would be Class 1 . For livestock, the TDS classes might be Class 2 for dairy animals, pigs and poultry, Class 3 for non-dairy cattle and up to Class 5 for sheep.
TABLE 5

Mean and modal values calculated for each of the components of the WQI for NAVIHEIM (Navicula heimansii Van Dam \& Kooyman)

\begin{tabular}{|l|c|c|c|c|}
\hline $\begin{array}{l}\text { NAVIHEIM } \\
\mathrm{n}=\mathbf{1 2}\end{array}$ & $\begin{array}{c}\mathbf{m g} \cdot \boldsymbol{\ell}^{-1} \\
\text { Mean }\end{array}$ & $\begin{array}{c}\text { Class } \\
\text { Mean }\end{array}$ & $\begin{array}{c}\left(\mathbf{m g} \cdot \boldsymbol{\ell}^{-1}\right) \\
\text { Mode }\end{array}$ & $\begin{array}{c}\text { Class } \\
\text { Mode }\end{array}$ \\
\hline $\mathrm{Ca}^{++}$ & 2.67 & 1 & 3.00 & 1 \\
$\mathrm{Cl}^{-}$ & 42.83 & 1 & 42.00 & 3 \\
$\mathrm{EC}(\mathrm{mS} . \mathrm{m}-1)$ & 45.64 & 1 & - & 1 \\
$\mathrm{~F}^{-}$ & 0.05 & 2 & 0.10 & 1 \\
$\mathrm{~K}^{+}$ & 0.75 & 1 & 0.70 & 1 \\
$\mathrm{Mg}^{++}$ & 3.83 & 1 & 4.00 & 1 \\
$\mathrm{Na}^{+}$ & 26.17 & 1 & 28.00 & 2 \\
$\mathrm{NH}_{4}^{-}$ & 0.00 & 1 & 0.00 & 1 \\
$\mathrm{NO}_{3}^{-}$ & 0.02 & 1 & 0.00 & 1 \\
$\mathrm{pH}^{-}$ & 7.21 & 2 & - & 2 \\
$\mathrm{H}_{2} \mathrm{PO}_{4}^{-}$ & 0.03 & 1 & - & 1 \\
$\mathrm{SiO}^{-}$ & 2.28 & 2 & 2.10 & 1 \\
$\mathrm{SO}_{4}^{--}$ & 9.50 & 1 & 7.00 & 1 \\
$\mathrm{Alkalinity}_{\mathrm{TDS}}$ & 12.17 & 1 & 14.00 & 2 \\
$\mathrm{Mean}^{-}$class without $\mathrm{pH}$ & 100.83 & 1 & - & 1 \\
\hline
\end{tabular}

In biomonitoring river water quality using diatoms, reference to an actual water component concentration in units of $\mathrm{mg} \cdot \ell^{-1}$ is not very useful because TDS comprises up to 4-digit whole numbers whereas ammonium normally falls into values of a single whole number. When a WQI value is used, a Class 3 is the same for all water quality components. The same applies to other uses. If a user is aware that there are 5 water quality classes, then a reported WQI has immediate interpretative value.

Bate et al. (2004) have reported the WQI values for all the dominant benthic diatoms located thus far in the rivers of South Africa. If an epipelic diatom is dominant at a river site then the WQI for that species immediately indicates the average WQ for the site at which it was collected. There are too few data at present to use this WQI system as more than a guide and because the values are not likely to be normally distributed until more data are collected. We have calculated both the mean and modal water quality values for a number of species. As $\mathrm{n}$ for each species increases, so the mean and mode merge. However, until more data are available, both the mean WQI and the modal WQI should be reported with their respective standard errors. An example of the difference between the mean and modal WQC values is shown in Table 5. The data in Table 5 show that in the case of NAVIHEIM(Navicula heimansii van Dam and Kooyman), both the mean and modal classes were rather similar, but not identical.

\section{Acknowledgements}

We would like to thank Professor OAM Lewis most sincerely for his constructive criticism during the preparation of this manuscript. We are especially grateful to the Water Research Commission (WRC), not only for funding this project, but also for their continued enthusiasm and support. Funds were also supplied by way of a University of Port Elizabeth research grant to one of us (GCB). We are grateful to the Department of Water Affairs and Forestry (DWAF) who assisted during the collection of the samples from most of the rivers. The Department also analysed the water samples 
through Resource Quality Services at Roodeplaat. We were generously supported by staff of the Botany Department at the University of Port Elizabeth, especially Mrs J Kritzinger, Dr DR du Preez, Mr A Gouws and Mr M Brassil. The members of the WRC Steering Committees provided considerable assistance in their very constructive criticism over a long period.

\section{References}

ARCHIBALD REM (1983) The Diatoms of the Sundays and Great Fish Rivers in the Eastern Cape Province of South Africa. Cramer, Vaduz. 431 pp.

BAIRD D, HANEKOM NM and GRINDLEY JR (1986) Estuaries of the Cape. Report No.23: Swartkops. CSIR Research Report 422, Stellenbosch. 82 pp.

BATE GC, ADAMS JB and SMAILES PA (2004) Benthic Diatoms in The Rivers and Estuaries of South Africa. WRC Report No. 1107.

BINNING KA (1999) An Investigation into the Relationship between Water Quality, Sediment and Meiofaunal Communities of the Swartkops River Ecosystem. Ph.D. thesis, University of Port Elizabeth, Port Elizabeth.

BORCHARDT MA (1996) Nutrients. In: Stevenson RJ, Bothwell ML and Lowe RL (eds.) Algal Ecology. Freshwater Benthic Ecosystems. Academic Press, San Diego. 183-227.

CHAMBERS PA, PREPAS EE and GIBSON K (1992) Temporal and spatial dynamics in riverbed chemistry: The influence of flow and sediment composition. Can. J. Fish. Aq. Sci. 49 2128-2140.

CHESSMAN B, GROWNS I, CURREY J and PLUNKETT-COLE N (1999) Predicting diatom communities at the genus level for the rapid biological assessment of rivers. Freshwater Biol. 41 317-331.

CATTANEO A and PRAIRIE YT (1995) Temporal variability in the chemical characteristics along the Riviere de l'Achigan: How many samples are necessary to describe stream chemistry? Can. J. Fish. Aq. Sci. 52 828-835.

CHOLNOKY BJ (1953) Diatomeenassoziationen aus dem Hennopsrivier bei Pretoria. Verh. Zool.-Bot. Ges. in Wien. 93 135-149.

CHOLNOKY BJ (1960) Beiträge zur Kentniss der Ökologie der Diatomeen in dem Swartkops-Bache nahe Port Elizabeth (SüdostKapland). Hydrobiol. 16 229-287.

CHOLNOKY BJ (1968) Die Ökologie der Diatomeen in Binnengewässern. J. Cramer, Weinheim. 699 pp.

FRANCE RL and PETERS RH (1992) Temporal variance function for total phosphorus concentration. Can. J. Fish. Aq. Sci. 49 975977.

FRITZ SC, JUGGINS S, BATTARBEE RW and ENGSTROM DR (1991) Reconstructing of past changes in salinity and climate using a diatom-based transfer function. Nature 352 706-708.

GASSE F, JUGGINS S and Khelifa LB (1995) Diatom-based transfer functions for inferring past hydrochemical characteristics of African lakes. Palaeogeogr. Palaeoclim. Palaeoecol. 117 31-54.

GORDON ND, McMAHON TA and FINLAYSON BL (1992) Stream Hydrology. An Introduction for Ecologists. John Wiley \& Sons, Chichester. 526 pp.

HOHLS DR (1996) National Biomonitoring Programme for Riverine Ecosystems: Framework Document for the Programme. NBP report series No. 1. Inst. for Water Quality Studies. Dept. Water Affairs and For. Pretoria. 39 pp.

JOHN J (1998) Diatoms: Tools for Bioassessment of River Health. A Model for South-Western Australia. Water and Rivers Com. Perth. 388 pp.

KELLY MG and WHITTON BA (1995) The Trophic Diatom Index: a new index for monitoring eutrophication in rivers. J. App. Phycol. 7 433-444.

KELLY MG, CAZAUBON A, CORING E, DELL'UOMO A, ECTOR L, GOLDSMITH B, GUASCH H, HÜRLIMANN J, JARLMAN A, KAWECKA B, KWADRANS J, LAUGASTE R, LINDSTROM E-A. LEITAO M, MARVAN P, PADISÁK J, PIPP E, PRYGIEL J, ROTT E, SABATER S, VAN DAM H and VIZINET J (1998) Recommendations for the routine sampling of diatoms for water quality assessments in Europe. J. Appl. Phycol. 10 215224.

KÖPKE D (1988) The climate of the Eastern Cape. In: Bruton MN and Gess FW (eds). Towards an Environmental Plan for the Eastern Cape. Rhodes University, Grahamstown. 44-52.

LANGE-BERTALOT H (ed.) 2000 Icon. Diatom. 7 Koeltz Scientific Books, Germany. 925 pp.

LOBO EA, KATOH K and ARUGA Y (1995) Response of epilithic diatom assemblages to water pollution in rivers in the Tokyo metropolitan area, Japan. Freshwater Biol. 34 191-204.

LOBO EA, CALLEGARO VLM, BENDER EP and ASAI K (1998) Water quality assessment of rivers of Southern Brazil using epilithic diatom assemblages. $15^{\text {th }}$ Int. Diatom Symp. Perth, Aust. (Abstract).

LOEZ CR and TOPALIAN ML (1999) Use of algae for monitoring rivers in Argentina with a special emphasis for Reconquista River (region of Buenos Aires). In: Prygiel J, Whitton BA and Bukowska $\mathrm{J}$ (eds.) Use of Algae for Monitoring Rivers III. 72-83. Agence de l'Eau Artois-Picardie, Douai.

LOWE RL and PAN Y (1996) Benthic algal communities as biological indicators. In: Stevenson RJ, Bothwell ML and Lowe RL (eds). Algal Ecology. Freshwater Benthic Ecosystems. Academic Press, San Diego. 705-739.

MACKAY HM (1993) The Impact of Urban Runoff on the Water Quality of the Swartkops Estuary: Implications for Water Quality Management. WRC, Pretoria.

PIETERSE AJH and VAN ZYL JM (1988) Observations on the relation between phytoplankton diversity and environmental factors in the Vaal River at Balkfontein, South Africa. Hydrobiol. 169 199-207.

POULIN M and WILLIAMS DM (1998) Conservation of diatom biodiversity: A perspective. $15^{\text {th }}$ Int. Diatom Symp. Perth, Aust. (Abstract).

PRYGIEL J, WHITTON BA and BUKOWSKA J (eds.) (1999) Use of Algae for Monitoring Rivers III. Agence de L'Eau Artois-Picardie, Douai. 271 pp.

PRYGIEL J and COSTE M (1993) The assessment of water quality in the Artois-Picardie water basin (France) by the use of diatom indices. Hydrobiol. 269/270 343-349.

PRYGIEL J and COSTE M (1999) Progress in the use of diatoms for monitoring rivers in France. In: Prygiel $\mathrm{J}$ Whitton BA and Bukowska J (eds.) Use of Algae for Monitoring Rivers III. Agence de l'Eau Artois-Picardie, Douai. 165-179.

ROTHFRITZ H, JUTTNER I, SUREN AM and ORMEROD SJ (1997) Epiphytic and epilithic diatom communities along environmental gradients in the Nepalese Himalaya: implications for the assessment of biodiversity and water quality. Archiv. für Hydrobiol. 138 465-482.

SCHOEMAN FR (1979) Diatoms as indicators of water quality in the upper Hennops river. J. Limnol. Soc. South. Afr. 5 73-78.

SCHOEMAN FR and ARCHIBALD REM (1986) Observations on Amphora species (Bacillariophyceae) in the British museum (Natural Hystory). V. Some species from the subgenus Amphora. S. Afr. J. Bot. 52 425-437.

STEVENSON RJ AND PAN Y (1999) Assessing environmental conditions in rivers and streams with diatoms. In: Stoermer EF and Smol JP (eds.) The Diatoms: Applications for the Environmental and Earth Sciences. Cambridge University Press, Cambridge. 1140.

UYS MC, GOETSCH P-A. and O'KEEFFE JH (1996) National Biomonitoring Programme for Riverine Ecosystems: Ecological Indicators, a Review and Recommendations. NBP Report Series No. 4. Inst. for Water Quality Studies, Dept. Water Affairs and Forestry, Pretoria. 92 pp.

VAN DAM H, MERTENS A and SINKELDAM J (1994) A coded checklist and ecological indicator values of freshwater diatoms from the Netherlands. Neth. J. Aquat. Ecol. 28 177-133.

VAN DER MOLEN JS (2000) Diatoms as Indicators of Water Quality in South African River Systems. Ph.D. thesis, Department of Botany, University of Port Elizabeth. 128 pp + Appendix. 